\title{
TREND OF HBSAG SEROPREVALENCE AMONG BLOOD DONORS IN A NIGERIAN TEACHING HOSPITAL: A FIVE-YEAR RETROSPECTIVE STUDY
}

\author{
WINIFRED AITALEGBE OJIEABU ${ }^{1 *}$, WASIU ADEDEJI MUKAILA ${ }^{1}$, CHRISTABEL \\ EBABHI OJIEABU ${ }^{2}$, JOHN ARUTE ${ }^{3}$, SHAKIRAT IYABO BELLO ${ }^{4}$ AND SIMEON \\ JAMES-EDWARDS ${ }^{1}$ \\ 1'Department of Clinical Pharmacy and Biopharmacy, Faculty of Pharmacy, Olabisi \\ Onabanjo University, Sagamu Campus, Sagamu, Ogun State, Nigeria \\ ${ }^{2}$ Obafemi Awolowo College of Health Science, Olabisi Onabanjo University, Sagamu \\ Campus, Sagamu, Ogun State, Nigeria \\ ${ }^{3}$ Department of Clinical Pharmacy and Pharmacy Administration, Faculty of Pharmacy, \\ Delta State University, Abraka, Nigeria \\ ${ }^{4}$ Department of Clinical Pharmacy and Pharmacy Practice, Faculty of Pharmaceutical \\ Sciences, University of Ilorin, Ilorin, Nigeria
}

Published online: 23 November 2021

To cite this article: WINIFRED AITALEGBE OJIEABU, WASIU ADEDEJI MUKAILA, CHRISTABEL EBABHI OJIEABU, JOHN ARUTE, SHAKIRAT IYABO BELLO \& SIMEON JAMES-EDWARDS (2021) Trend of HBsAg seroprevalence among blood donors in a Nigerian teaching hospital: A five-year retrospective study, Malaysian Journal of Pharmaceutical Sciences. 19(2): 87-96, https://doi.org/10.21315/mjps2021.19.2.6

To link to this article: https://doi.org/10.21315/mjps2021.19.2.6

\begin{abstract}
World Health Organization (WHO) classified Nigeria as a hyper-endemic hepatitis B surface antigen (HBsAg) positive nation with prevalence $\geq 8 \%$. This study intends to add information that could strengthen established database to improve awareness and prevention of hepatitis $B$ virus (HBV) infection. We aimed to evaluate seroprevalence and trend of $\mathrm{HBs} A g$ among blood donors in Olabisi Onabanjo University Teaching Hospital (OOUTH), Sagamu, Ogun State, Nigeria over a five-year period. Data from records of 7,102 individuals aged $\geq 20$ years old who donated blood to blood bank in this hospital from January 2012 to December 2016 were analysed for gender, age, number of donors per year and HBsAg status. Data analysis was done with Statistical Package for Social Sciences software. $P \leq 0.05$ was considered statistically significant. Males were in the majority (6,547 [92.2\%]). Age 30-39 years old was the major group (3,052 [43.0\%]). Pooled HBsAg seroprevalence was $486(6.8 \%)$. Females had the highest HBsAg seroprevalence across board with highest rate of $10(19.6 \%)$ in year 2012 and pooled prevalence of $73(13.2 \%)$. Age group of $\geq 50$ years old had highest HBsAg seroprevalence 39 (8.5\%) while age group of 20-29 years old had least 128 (5.8\%). Stratified HBsAg positivity decreased steadily from year 2012 to year 2016. This location was HBV intermediate-endemic. There were age, gender and
\end{abstract}

*Corresponding author: natbelpharmacy@yahoo.com

(c) Penerbit Universiti Sains Malaysia, 2021. This work is licensed under the terms of the Creative Commons Attribution (CC BY) (http://creativecommons.org/licenses/by/4.0/). 
yearly seroprevalence of HBsAg related trends which could be leveraged upon in finding effective preventive measures against the disease. We recommend mass vaccination by government against HBV infection in addition to provision of sensitive blood investigational equipment.

Keywords: Trend, Seroprevalence, HBsAg, Blood donors, Teaching hospital

\section{INTRODUCTION}

Hepatitis B infection is one of the world's commonest viral hepatitis caused by hepatitis B virus (HBV). Roughly two billion of the world's population are reported to be affected by this infection (Ott et al. 2012). World Health Organization (WHO) estimated the number of global HBV chronic carriers to be 325 million people, of which approximately 60 million of the people are located in the African region (WHO 2017). HBV can be transmitted from infected persons to unprotected persons through various modes including mother-child (during pregnancy, childbirth and breastfeeding), unprotected sexual intercourse, sharing needles especially by intravenous drug users and blood transfusion (Brooks et al. 2007). Prevalence of HBV infection across the globe based on geographical areas ranges from high ( $\geq 8 \%$ ), examples: Africa and Asia, intermediate ( $2 \%-7.9 \%)$, examples: Southern and Eastern Europe to low $(\leq 2 \%)$, examples: North America and Australia (Te and Jensen 2010). In sub-Saharan Africa, infection of HBV has been hyperendemic and is recognised as the main cause of chronic liver disease such as hepatocellular carcinoma (Ndububa et al. 2005; Ola and Odaibo 2007). About $12.5 \%$ of patients transfused with blood in subSaharan Africa are feared to have encountered post-transfusion hepatitis irrespective of the safety measures imbibed during the pre-and transfusion processes (Nambei, RawagoMandjiza and Gbangbangai 2016; Ankouane et al. 2016).

The chronic nature of this virus makes it a disease of public importance. This should draw meaningful attention from any government that cares for the health of its populace especially as it is established that the chronicity makes the virus live in the host's liver for life (Jia and Zhuang 2007). This state of chronicity makes it possible for the individual to spread the virus to other innocent lives as well as the likelihood of coming down with diseases of the liver such as cancer and cirrhosis (Ndububa et al. 2005; Ola and Odaibo 2007). The dreadful fact about this infection is that the carriers do not usually have symptoms of the disease and therefore do not know they have the virus but can transmit it to other people (Nelson et al. 2000). Blood screening is, therefore, a mandatory test for transfusion safety as it gives an opportunity to detect seroprevalence markers (hepatitis B surface antigen [HBsAG]) for HBV prevalence in individuals (Afsar et al. 2010).

Previous results from some geographical areas in Nigeria found high rates of HBsAg seroprevalence among different groups including blood donors. Examples of such rates among blood donors included the following: $23.4 \%$ in llorin, $20 \%$ in Benue state and $14.3 \%$ in Jos, respectively, found by Bada et al. (1996), Alao et al. (2009) and Uneke et al. (2014).

Since hepatitis B infection is highly transmittable, especially among blood donors, it is of great importance to enforce strict adherence to screening of blood donors for any type of infectious diseases especially HBsAg, human immunodeficiency virus (HIV) and the likes in order to avert transfusion of infectious blood to innocent blood recipients. This study aims to evaluate trend and seroprevalence of HBsAg among blood donors in Olabisi Onabanjo University Teaching Hospital (OOUTH), Sagamu, Ogun State, Nigeria over a five-year period. The study intends to add information that could strengthen established

Malay J Pharm Sci, Vol. 19, No. 2 (2021): 87-96 
database to improve awareness and prevention of HBV infection. It would also be useful to health policy makers in strategising cost-effective interventions to reduce the spread of HBV among the populace. As per our knowledge, this is the first major assessment of this nature in this teaching hospital.

\section{METHODS}

\section{Study Area}

This was a five-year retrospective study carried out among blood donors at the blood bank unit of OOUTH, Sagamu, Ogun State, Nigeria. Sagamu is a major city of Ogun state, Southwestern Nigeria with an estimated 3,751,410 inhabitants according to 2016 population census and functions as the headquarters of Sagamu local government area. The only government teaching hospital, i.e. OOUTH is located in Sagamu town to cater majorly for the inhabitants of the state and patients from neighbouring states such as Lagos, Oyo and beyond who also patronise this hospital.

\section{Study Population}

The study was made up of 7,102 individuals, which comprised voluntary donors and those called upon to make blood donations to needing patients though the two categories were not separated in the yearly records reviewed. Records of those who donated blood to the blood bank from January 2012 to December 2016 (both years inclusive) were assessed for information such as age, gender, number of donors per year and HBsAg status. Our sample comprised donors aged 20 years old and above. According to the operating procedures followed in this institution, all intending blood donors undergo compulsory screening for diseases such HIV, HBV, hepatitis $\mathrm{C}$ virus (HCV) and a host of others. The test for the detection of $\mathrm{HBsAg}$ among the blood donors employed the one step immunochromatographic kits (Enzyme-linked immunosorbent assay kits, Abbott Laboratories, Chicago, IL, USA) based on the manufacturer's instructions.

\section{Exclusion Criteria}

Non-blood donors, age less than 20 years old and pediatric groups were excluded from this study.

\section{DATA ANALYSIS}

Data were checked before being entered into Microsoft Excel for sorting. Further analysis was performed using Statistical Package for Social Sciences (SPSS) software version 20 (Chicago, Illinois) for descriptive and comparative analyses. $P$-value $\leq 0.05$ was considered statistically significant. Prevalence of HBV was determined by the proportion of HBsAg seroprevalence among the blood donors. Results are expressed as frequency and percentage. 


\section{Ethical Consideration}

Permission to assess the blood donation files was granted by OOUTH ethics committee before the commencement of the study (OOUTH Ethics Committee only grants permission for existing data to be assessed but not an approval).

\section{RESULTS}

The period evaluated indicated that a total number of 7,102 individuals donated blood at the blood bank unit of OOUTH. Above three quarters of this number, 6,547 (92.2\%) were males while $555(7.8 \%)$ were females, indicating that males were significantly higher than females with ratio of approximately 12:1 $(P \leq 0.05)$. Males were also higher across board (from years 2012-2016). Age group 30-39 years old had the highest presentation 3,052 (43.0\%), while age group $\geq 50$ years old had the least presentation $458(6.4 \%)$ as shown in Table 1 . The pooled (yearly prevalence from 2012-2016) seroprevalence of HBsAg among the blood donors was $486(6.8 \%)$. Yearly, HBsAg positivity decreased steadily with the highest rate, $28(10.4 \%)$ in year 2012 and least, $69(4.8 \%)$ in year 2016 as displayed in Table 2. Females had the highest HBsAg seroprevalence across board with the highest rate of $10(19.6 \%)$ in year 2012 and pooled prevalence of $73(13.2 \%)$ while males' highest rate of $18(8.2 \%)$ was also in year 2012 and pooled prevalence of $413(6.3 \%)$. The following age groups had the highest and lowest rates of pooled HBsAg seroprevalence, respectively: age group $\geq 50$ years old, 39 (8.5\%) and age group 20-29 years old, $128(5.8 \%)$ as indicated in Table 3.

Table 1: Gender and age of blood donors at the blood bank unit of OOUTH (2012-2016).

\begin{tabular}{lllllll}
\hline Variable & $\mathbf{2 0 1 2}$ & $\mathbf{2 0 1 3}$ & $\mathbf{2 0 1 4}$ & $\mathbf{2 0 1 5}$ & $\mathbf{2 0 1 6}$ & $\begin{array}{l}\text { Pooled } \\
\text { total (\%) }\end{array}$ \\
& $\mathbf{N}(\mathbf{\%})$ & $\mathbf{N ~ ( \% )}$ & $\mathbf{N ~ ( \% )}$ & $\mathbf{N ~ ( \% )}$ & $\mathbf{N ~ ( \% )}$ & \\
\hline $\begin{array}{l}\text { Gender } \\
\quad \text { Male }\end{array}$ & $219(81.1)$ & $1736(93.6)$ & $2142(92.9)$ & $1117(91.2)$ & $1333(92.1)$ & $6547(92.2)$ \\
$\quad$ Female & $51(18.9)$ & $118(6.4)$ & $163(7.1)$ & $108(8.8)$ & $115(7.9)$ & $555(7.8)$ \\
\hline Total & $270(100)$ & $1854(100)$ & $2305(100)$ & $1225(100)$ & $1448(100)$ & $7102(100)$ \\
\hline Age (years & & & & & & \\
old) & & & & & & \\
$20-29$ & $102(37.8)$ & $444(23.9)$ & $643(27.9)$ & $380(31.0)$ & $648(44.8)$ & $2217(31.2)$ \\
$30-39$ & $149(55.2)$ & $803(43.3)$ & $1006(43.6)$ & $415(33.9)$ & $679(46.9)$ & $3052(43.0)$ \\
$40-49$ & $18(6.7)$ & $403(21.7)$ & $533(23.1)$ & $306(25.0)$ & $115(7.9)$ & $1375(19.4)$ \\
$\geq 50$ & $1(0.4)$ & $204(11.0)$ & $123(5.3)$ & $124(10.1)$ & $6(0.4)$ & $458(6.4)$ \\
\hline Total & $270(100)$ & $1854(100)$ & $2305(100)$ & $1225(100)$ & $1448(100)$ & $7102(100)$ \\
\hline
\end{tabular}

Malay J Pharm Sci, Vol. 19, No. 2 (2021): 87-96 
Table 2: Yearly and pooled seropositivity of HBsAG among blood donors at OOUTH.

\begin{tabular}{lllllll}
\hline HBsAG & $\mathbf{2 0 1 2}$ & $\mathbf{2 0 1 3}$ & $\mathbf{2 0 1 4}$ & $\mathbf{2 0 1 5}$ & $\mathbf{2 0 1 6}$ & Pooled \\
\hline Positive & $28(10.4)$ & $143(7.7)$ & $168(7.3)$ & $78(6.4)$ & $69(4.8)$ & $486(6.8)$ \\
Negative & $242(89.6)$ & $1711(92.3)$ & $2137(92.7)$ & $1147(93.6)$ & $1379(95.2)$ & $6616(93.2)$ \\
\hline Total & $270(100)$ & $1854(100)$ & $2305(100)$ & $1225(100)$ & $1448(100)$ & $7102(100)$ \\
\hline
\end{tabular}

Table 3: Gender and age stratification of yearly seroprevalence of HBsAG among blood donors at OOUTH.

\begin{tabular}{|c|c|c|c|c|c|c|}
\hline Variable & 2012 & 2013 & 2014 & 2015 & 2016 & Pooled \\
\hline & $\begin{array}{l}\text { Positive } \\
n / N(\%)\end{array}$ & $\begin{array}{l}\text { Positive } \\
n / N(\%)\end{array}$ & $\begin{array}{l}\text { Positive } \\
n / N(\%)\end{array}$ & $\begin{array}{l}\text { Positive } \\
n / N(\%)\end{array}$ & $\begin{array}{l}\text { Positive } \\
n / N(\%)\end{array}$ & $\begin{array}{l}\text { Positive } \\
n / N(\%)\end{array}$ \\
\hline \multicolumn{7}{|l|}{ Gender } \\
\hline Male & $18(8.2)$ & $131(7.5)$ & $140(6.5)$ & $61(5.5)$ & $63(4.7)$ & $413(6.3)$ \\
\hline Female & $10(19.6)$ & $12(10.2)$ & $28(17.2)$ & $17(15.7)$ & $6(5.2)$ & $73(13.2)$ \\
\hline \multicolumn{7}{|c|}{ Age (years old) } \\
\hline $20-29$ & $5(4.9)$ & $29(6.5)$ & $50(7.8)$ & $20(5.3)$ & $24(3.7)$ & $128(5.8)$ \\
\hline 30-39 & $21(14.1)$ & $62(7.7)$ & $62(6.2)$ & $36(8.7)$ & $33(4.9)$ & $214(7.0)$ \\
\hline $40-49$ & $2(11.1)$ & $34(8.4)$ & $40(7.5)$ & $17(5.6)$ & $12(10.4)$ & $105(7.6)$ \\
\hline$\geq 50$ & $0(0.0)$ & $18(8.8)$ & $16(13.0)$ & $5(4.0)$ & $0(0.0)$ & $39(8.5)$ \\
\hline Total & $28(100)$ & $143(100)$ & $168(100)$ & $78(100)$ & $69(100)$ & $486(6.8)$ \\
\hline
\end{tabular}

Notes: $N=$ Number assessed in each group; $n=$ number positive in each group assessed

\section{DISCUSSION}

Blood serves as the body's transport system in addition to being the defense against infections. People need blood at one time or the other to replenish their blood deficiencies due to disease states or accidents and the safety of such blood is of paramount importance especially to the receiver. This study found HBsAg seroprevalence of $6.8 \%$ in this location, indicating HBV intermediate endemicity status (Te and Jensen 2010). This value compares with earlier results in Nigeria (Umolu, Okoror and Orhue 2005; Ikerionwu 2018) and in other countries (Osei, Yao and Agboli 2017; Negash et al. 2019). Our prevalence of 6.8\% is lower than Nigerian's national HBsAg prevalence rates of $14.0 \%$ and $12.2 \%$, respectively, found by previous studies (Musa et al. 2015; Olayinka et al. 2016), also lower than results from some locations in Nigeria (Alao et al. 2009; Uneke et al. 2014), outside Nigeria (Elfaki, Eldour and Elsheikh 2008; Walana, Hokey and Ahiaba 2014) but higher than the following (Muktar, Suleiman and Jones 2005; Singh, Bhat and Shastry 2009; Treitinger et al. 2004) also found among blood donors.

In this present study, the highest blood donation gender was male (Okonko et al. 2010; Mba et al. 2018). This could be understood from our cultural point of view where women are regarded as the weaker sex and therefore may not be encouraged to donate blood. Secondly, many women in this part of the world might not be willing or confident enough to donate blood, as most may believe that their monthly menstrual flow takes a toll 
on them (Erhabor, Adias and Mainasara 2013; Shaz et al. 2009). The highest age group donating blood in this study was the lower age group (20-39 years old), indicating the most active group in the age distribution. This finding is similar to previous ones (Okonko et al. 2010; Mba et al. 2018), who also found lower age groups' involvement in blood donation activity to be higher than older age groups.

There was gender impact of HBV prevalence in this study as female blood donors had higher pooled prevalence as well as stratified prevalence rates across board than their male counterparts. This finding compares with Osei, Yao and Agboli (2017), and Bwogi, Braka and Makumbi (2009) but inconsistent with these earlier studies (Uneke et al. 2014; Singh, Bhat and Shastry 2009). It should be noted that an earlier research (Okonko et al. 2010) conducted in this same state's capital city reported the same higher HBsAg seroprevalence among females than males. This high HBsAg seroprevalence found among the females should be given the attention it deserves because it is an indication that many women in and around this study location may transit to reservoirs status of HBV without symptoms. This could lead to continuous transmission of the virus to many innocent individuals through horizontal and vertical modes especially among women who do not attend standard hospitals for their antenatal care. In addition, such women are at risk for liver cancer and cirrhosis. This high HBsAg seroprevalence may also be suggestive of the fact that these women are engaged in sexual promiscuity without weighing the consequences. The Centre for Disease Control's (2002) finding showed that most women infected with HBV are through sexual contact with positive partners. Based on our finding, we recommend mass vaccination of the populace which could be targeted against eradication of this disease. Immunisation could be provided by the government free of charge for the population at risk while others could be highly subsidised by the same. We also recommend community-based education through each community head in order to sensitise individuals of the nature of infection and prevention of the virus.

There was also age effects on HBV prevalence rates as the prevalence increased with increased age. Age of 30 to $\geq 50$ years old in this study encountered the highest HBsAg prevalence while age 20-29 years old had the least prevalence. This was also found in earlier studies (Rodenas, Bacasen and Que 2006; Lopez-Balderas et al. 2015) but the following studies (Walana, Hokey and Ahiaba 2014; Ezegbudo et al. 2014) found higher HBV prevalence in lower age groups than higher age groups. This may be traced to the issue of chronic nature of the virus although further research studies could be directed to this area. We found a decreasing trend in HBsAg prevalence over the five years reviewed as our yearly prevalence of HBsAg decreased steadily across board from 2012 down to 2016, a finding comparable to that in an earlier work (Osei, Yao and Agboli 2017) but different from that of Mba et al. (2018), whose trend increased steadily before a decrease. This decreasing rate in our study could be due to the awareness created among the blood donors during counseling/health talk sessions, which the staff members of the blood bank department hold with the donors preceding the bleeding session.

Although HBV infection is a vaccine-preventable disease, Nigeria's HBV status has remained on the high side despite the fact that HBV vaccine has been added to the National Programme on Immunization and Partner since 2004 (National Programme on Immunization and Partner 2002). Unlike in Nigeria, vaccination against HBV infection including safety health practices in developed nations of the world such as America, Europe and Australia have been found to reduce the prevalence of chronic HBV infection in those regions (Ott et al. 2012).

Malay J Pharm Sci, Vol. 19, No. 2 (2021): 87-96 


\section{CONCLUSION}

This study found this location to be HBV intermediate endemic. There were age, gender and yearly related trends of the infection, which could be leveraged upon in finding effective solutions out of the disease. The information gathered from this study is useful in addressing the prevention of $\mathrm{HBV}$ infection and thereby could help in reducing the high endemicity status of Nigeria. We subscribe to an earlier study (Ezegbudo et al. 2014) which recommended that all government hospitals/health centres should have HBV clinics for enlightenment (community education) in addition to being infectious screening centres. Although we found a yearly decrease in seroprevalence of HBsAg across board, we however recognise the fact that HBV carriers are able to transmit the virus to others when there are no adequate screening procedures. We, therefore, advocate mass vaccination by the government against HBV infection.

In addition, there should be provision of adequate and sensitive blood investigational equipment at every certified blood bank location across Nigeria to ensure effective screening of blood donors prior to bleeding. This will highly limit and prevent transfusion of unsafe blood to needing patients. This comes in the light of a previous finding (Adeyemi, Omolade and Raheem-Ademola 2013) of some less sensitive blood test kits employed in blood investigation in this country.

\section{LIMITATION OF THE STUDY}

The first limitation in this study is that the study was conducted in one tertiary hospital, which is not enough to be extrapolated to the country's endemicity status. Secondly, the sample size was small which could not have captured the extent of the infection in the country.

\section{REFERENCES}

ADEYEMI, A. A., OMOLADE, O. A. \& RAHEEM-ADEMOLA, R. R. (2013) Immunochromatographic testing method for hepatitis B, C in blood donors, Journal of Antivirals and Antiretrovirals, S3. https://doi.org/10.4172/jaa.S3-005

AFSAR, I., GUNGOR, S., SENER, A. G. \& YURTSEVER, S. G. (2010) The prevalence of HBV, HCV and HIV infections among blood donors in Izmir, Turkey, Indian Journal of Medical Microbiology, 26(3): 288-289. https://doi.org/10.1016/S0255-0857(21)01891-0

ALAO, O., OKWORI, E., EGWU, C. \& AUDU, F. (2009) Seroprevalence of hepatitis B surface antigen among prospective blood donors in an urban area of Benue state, The Internet Journal of Hematology, 5(2). https://doi.org/10.5580/1c

ANKOUANE, F., NOAH NOAH, D., ATANGANA KAMGAING, M. M., SIMO, R., GUEKAM, P. R. \& BIWOLE SIDA, M. (2016) Seroprevalence of hepatitis B and C viruses, HIV-1/2 and syphilis among blood donors in the Yaounde Central Hospital in the centre region of Cameroon, Transfusion clinique et biologique: Journal de la Societe Francaise de Transfusion Sanguine, 23(2): 72-77. https://doi.org/10.1016/j.tracli.2015.11.008 
BADA, A. S., OLATUNJI, P. O., ADEWUYI, J. O., ISENIYI, J. O. \& ONILE, B. A. (1996) Hepatitis B surface antigenaemia in Ilorin, Kwara State, Nigeria, Central African Journal of Medicine, 42: 139-141.

BROOKS, G. F., CAROLL, K. C., BUTEL, J. S. \& MORSE, S. A. (2007) Medical Microbiology, 24 ${ }^{\text {th }}$ edition, pp. 425-443 (New York, USA: McGraw Hill Publishers).

BWOGI, J., BRAKA F. \& MAKUMBI, I. (2009) Hepatitis B infection is highly endemic in Uganda: Findings from a national serosurvey, African Health Sciences, 9: 98-108.

CENTER FOR DISEASE CONTROL (2002) Prevalence of selected maternal behaviors and experiences: Pregnancy risk assessment monitoring system (PRAMS), MMWR, 51(55-2): 24.

MBA, J. M. E., BISSEYE, C., NTSAME NDONG, J. M., MOMBO, L. E., BENGONE C., MOUELET MIGOLET G. et al. (2018) Prevalent hepatitis B surface antigen among firsttime blood donors in Gabon, PLoS ONE, 13(4): e0194285. https://doi.org/10.1371/journal. pone.0194285

ELFAKI, A. M., ELDOUR, A. A. \& ELSHEIKH, N. M. (2008) Sero-prevalence of immunodeficiency virus hepatitis $B$ and $C$ and syphilis among blood donors at El Obeid Teaching Hospital, West Sudan, Sudan Journal of Medical Sciences, 3(4): 333-338. https://doi.org/10.4314/sjms.v3i4.38555

ERHABOR, O., ADIAS, T. C. \& MAINASARA, A. (2013) Provision of safe blood transfusion services in a low income setting in West Africa. Case study of Nigeria. IN: L. V. Berhardt (Ed.), Blood transfusions: Procedures, risks and role in disease treatment, $1^{\text {st }}$ edition, pp. 1-58 (New York, USA Nova Science Publishers).

EZEGBUDO, C. N., AGBONLAHOR, D. E., NWOBU, G. O., IGWE, C. U., AGBA, M. I., OKPALA, H. O. \& IKARAOHA, C. I. (2004) The seroprevalence of hepatitis B surface antigen and human immunodeficiency virus among pregnant women in Anambra state, Nigeria, Shiraz E-Medical Journal, 5(2): 1-25.

IKERIONWU, B. (2018) Prevalence of hepatitis B surface antigen and hepatitis B core antibody among prospective blood donors in Abuja, Nigeria, Archive of Blood Transfusion Disorder, 1(5). https://doi.org/10.31031/ABTD.2018.01.000521

JIA, J. D. \& ZHUANG, H. (2007) A wining war against Hepatitis B virus infection in China, Chinese Medical Journal (Engl), 120(24): 2157-2158.

LOPEZ-BALDERAS, N., BRAVO, E., CAMARA, M. \& HERNANDEZ-ROMANO, P. (2015) Seroprevalence of hepatitis viruses and risk factors in blood donors of Veracruz, Mexico, Journal of Infection in Developing Countries, 9(3): 274-282. https://doi.org/10.3855/ jidc. 4812

MUKTAR, H. M., SULEIMAN, A. M. \& JONES, M. (2005) Safety of blood transfusion: Prevalence of hepatitis B surface antigen in blood donors in Zaria, Northern Nigeria, Nigerian Journal of Surgical Research, 7(3-4): 290-292.

Malay J Pharm Sci, Vol. 19, No. 2 (2021): 87-96 
MUSA, B. M., BUSSELL, I. S., BORODO, M. M., SAMAILA, A. A. \& FEMI, O. L. (2015) Prevalence of hepatitis B virus infection in Nigeria, 2000-2013: A systematic review and meta-analysis, Nigerian Journal of Clinical Practice, 18(2): 163-172.

NAMBEI, W. S., RAWAGO-MANDJIZA, D. \& GBANGBANGAI, E. (2016) Seroepidemiology of HIV, syphilis and hepatitis $B$ and $C$ viruses among blood donors in Bangui, Central African Republic, Medecine et Sante Tropicales, 26(2): 192-198. https://doi.org/10.1684/ mst.2016.0553

NATIONAL PROGRAMME ON IMMUNIZATION AND PARTNERS (2002) Five years National Strategic Plan 2003-2007, pp. 19-20 (Abuja, Nigeria: National Programme on Immunization).

NDUBUBA, D. A., OJO, O. S., ADETILOYE, V. A., DUROSINMI, M. A., OlASOdE B. J., FAMUREWA O. C. et al. (2005) Chronic hepatitis in Nigerian patients: A study of 70 biopsy-proven cases, West African Journal of Medicine, 24: 107-111.

NEGASH, M., AYALEW, M., GEREMEW, D. \& WORKINEH, M. (2019) Seroprevalence and associated risk factors for HIV, hepatitis B and C among blood donors in South Gondar District blood bank, Northwest Ethiopia, BMC Infectious Diseases, 19: 430. https://doi.org/10.1186/s12879-019-4051-y

NELSON, C. G., ILER, M. A., WOODS, C. W., BARTLETT, J. A. \& FOWLER, V. G. JR. (2000) Meningococcemia in a patient coinfected with hepatitis C virus and HIV, Emerging Infectious Diseases, 6(6): 646-648.

OKONKO, S. F. A., ALLI, J. A., OJEZELE, M. O., UDEZE, A. O., NWANZE, J. C., ADEWALE, O. G. et al. (2010) Seroprevalence of HBsAg antigenaemia among patients in Abeokuta, South Western Nigeria, Global Journal of Medical Research, 10(2): 40-49.

OLA, S. O. \& ODAIBO, G. N. (2007) Alfa-feto protein, HCV and HBV infections in Nigerian patients with primary hepatocellular carcinoma, Nigerian Medical Practice, 51: 33-35.

OLAYINKA, A. T., OYEMAKINDE, A., BALOGUN, M. S., AJUDUA, A., NGUKU, P., ADERINOLA, M. et al. (2016) American Journal of Tropical Medicine and Hygiene, 95(4): 902-907. https://doi.org/10.4269/ajtmh.15-0874

OSEI, E., YAO, L. S. \& AGBOLI, E. (2017) Sero-prevalence of hepatitis B infection among blood donors in a secondary care hospital, Ghana: A retrospective analysis. BMC Research Notes, 391(10): 1-5. https://doi.org/10.1186/s13104-017-2733-3

OTT, J. J., STEVENS, G. H., GROEGER, J. \& WIERSMA, S. T. (2012) Global epidemiology of hepatitis B virus infection: New estimates of age-specific HBsAg seroprevalence and endemicity, Vaccine, 30: 2212-2219. https://doi.org/10.1016/j.vaccine.2011.12.116

RODENAS, J. G., BACASEN, L. C. \& QUE, E. R. (2006) The prevalence of HBsAg(+) and anti $\mathrm{HCV}(+)$ among healthy blood donors at east avenue medical center, Quezon city, Philippines Journal of Gastroenterology, 2: 64-70. 
SHAZ, B. H., DEMMONS, D. G., HILLYER, K. L., JONES, R. E. \& HILLYER, C. D. (2009) Racial differences in motivators and barriers to blood donation among blood donors, Archives Pathology and Laboratory Medicine, 133(9): 1444-1447. https://doi.org/10.5858/133.9.1444

SINGH, K., BHAT, S. \& SHASTRY, S. (2009) Trend in seroprevalence of hepatitis B virus infection among blood donors of coastal Karnataka, India, Journal of Infection in Developing Countries, 3(5): 376-379.

TE, H. S. \& JENSEN, D. M. (2010) Epidemiology of hepatitis B and C viruses: A global overview, Clinics in Liver Diseases, 14: 1-21. https://doi.org/10.1016/j.cld.2009.11.009

TREITINGER, A., SPADA, C., FERREIRA, L. A., NETO, M. S., REIS, M., VERDI, J. C. et al. (2004) Hepatitis B and hepatitis C prevalence among blood donors and HIV-infected patients in Florianopolis, Brazil, Brazilian Journal of Infectious Diseases, 4: 192-196.

UMOLU, P. I., OKOROR, L. E. \& ORHUE, P. (2005) Human immunodeficiency virus (HIV) seropositivity and hepatitis B surface antigenemia (HBsAg) among blood donors in Benin City, Edo state, Nigeria, African Health Sciences, 5(1): 55-58.

UNEKE, C. J., OGBU, O., INYAMA, P. U., ANYANWU, G. I., NJOKU, M. O. \& IDOKO, J. H. (2014) Prevalence of hepatitis-B surface antigen among blood donors and human immunodeficiency virus-infected patients in Jos, Nigeria, Mem Inst Oswaldo Cruz, Rio de Janeiro, 100(1): 13-16. https://doi.org/10.1590/S0074-02762005000100002

WALANA, W., HOKEY, P. \& AHIABA, S. (2014) Sero-prevalence of hepatitis B virus infection among blood donors: A retrospective study in the Kintampo Municipal Hospital, Ghana, Open Journal of Medical Microbiology, 4: 64-69. https://doi.org/10.4236/ojmm.2014.41007

WORLD HEALTH ORGANIZATION (2017) www.who.int/mediacentre/news/releases/2017/ global-hepatitis-report/en/;2017 (28 September 2019).

Malay J Pharm Sci, Vol. 19, No. 2 (2021): 87-96 